\title{
Analysis on Ways of Cultivating Students' Interest in National Music
}

\author{
Xiaohong $\mathrm{Ma}$ \\ Department of Music and Dance, Ningxia Normal University, Guyuan, 756000, China
}

\author{
Keywords: Students; National music; Ways
}

\begin{abstract}
The music teachers shall apply effective ways to carefully care out popularization work of national music so as to let learners truly realize and feel the unique beauty of national music, improve learners' interest, complete the national music education in the subtle edification, and then realize the purpose of developing and improving learners' aesthetic ability and aesthetic accomplishment. This paper discusses the necessity of cultivating students' interest in national music, carries out direct image teaching through applying direct image teaching method and introducing Orff teaching method, and then explains the main ways of cultivating students' interest in national music.
\end{abstract}

\section{Introduction}

The music teaching focuses on improving students' music quality and cultivating learners' ability in appreciating social life and music art so that each learner can have noble soul and perfect personality characteristics. In order to realize this purpose, the music teaching can't be separated from China's traditional music education. The national music is a kind of music form which can reflect common people's life, and it is collectively created by people in the process of long-time productive labor and social practice activities. Due to wide territory in China, there is great difference in various aspects of national music style. For example, South China has warm climate, fertile soil, and beautiful natural landscape, and people's personality is gentle and cultivated, thus the music style is graceful and gentle; however, Northwest China has severe cold climate, people's life is hard, thus the music style is rigorous and deep. Therefore, the learners shall deeply know and feel various kinds of different social life, and fully contact and learn national music so as to motivate their strong interest in learning national music.

\section{Necessity of cultivating students' interest in national music}

China's national music is long-standing and well-established, extensive and profound; the traditional folk songs, Chinese folk art, traditional Chinese opera, and national instrumental music are organic parts of Chinese national culture. Therefore, to actively cultivate learners' enthusiasm in China's national music is especially important. The students' knowledge of China's national music shall be most fundamental, just like the situation that the foundation shall be tamped before a building is built. Learning China's national music is very important for young people; it not only can cultivate young students' aesthetic ability and improve their level of ideology morality, but also can promote continuous healthy development of their intelligence and body. China's national music has rich cultural connotation; due to great impact brought by modern life, most of students have little interest in national music, especially in national instruments and folk songs, and then the insufficient interest influences students' enthusiasm in learning national music. Faced with this phenomenon, the author thinks that the music teachers shall fully motivate learners' high enthusiasm in learning national music in classroom teaching, let the seed of national music take root and sprout in the learners' heart and become an important scenery in contemporary music life, which is also the responsibility which shall be undertaken by China's music educators. As people say, the national thing is the international thing. Through practically keeping the bright features of China's national music, it is able to let the music art stand in the forest of global national culture. Therefore, it can be said that actively cultivating learners' enthusiasm in exploring China's traditional national music is very necessary, 
and each music educator and amateur shall have the responsibility to deeply discuss how to cultivate young people's positive interest in national music.

\section{Main ways of cultivating students' interest in national music}

\section{To apply direct image teaching method}

In the music classroom, it is required to depend on teachers to exert their positive function to motivate learners' strong learning interest. The teachers are not only the main force which inherits and puts forward China's national music, but also the facilitators who cultivate students' interest in traditional national music in contemporary society. In view of this fact, except for applying music textbooks to implement the teaching, the music teachers shall also rationally apply their own ability, and professional skills to help learners to accept national music. On this basis, the teachers shall also seize learners' psychological features to implement the teaching. China's national music has a wide range, and the folk songs are one of important parts. In the folk song teaching, if the teachers apply contrast method to cultivate students' learning interest, the effect is very obvious. In the teaching for types of folk songs, the teachers can apply contrast method, that is, select different types of folk songs, and carry out some activities for exchange. The teachers shall require students to speak out the features of above songs, and summarize respective forms to help students to get a clear train of thought, form curiosity, and then motivate learning atmosphere. For example, the teachers can provide three familiar folk songs with different national features, and divide students into three different groups to complete the task; the content performed by each group focuses on different things; as for the performance of each group, it is able to let other two groups of students think about the bright features of this song through their performance and melody showed by the song. After each group completes their performance, the teachers can let them give a speech respectively, speak out the type of folk song according to their imagination, carry out exchange and contrast, and then summarize the difference. In this way, it is able to motivate the teaching atmosphere and let students firmly master corresponding knowledge.

On this basis, the teachers can also adopt rhetorical question method to improve learners' enthusiasm. Due to the difference in students' thinking, personality, and learning ability, the teachers shall make progression according to students' specific condition to motivate students' enthusiasm in exploring problems. As for one song, the teachers can propose the problems related to this song. For example, the teachers can ask students about which kind of emotion is expressed in the song, which kind of emotion shall be used in performance, what symbolic significance the song has, and other intuitive problems so as to let students truly understand important significance of China's national music and then let then get interest in national music. Once students carry out reasonable imagination, there will be better effect. People are animal with emotion, and one of important features of music art is that it has rich emotion; if the teachers carry out reasonable teaching in national music classroom, the learners will naturally become interested in national music. When the students' national music learning has corresponding foundation, it is required to cultivate students' overall coordination ability in national music learning, and this is closely related to improve learners' artistic quality and ability. After the students have corresponding quality and ability, they can show their talent and also deeply realize the powerful force of national music.

\section{To introduce Orff teaching method}

In the process of national music teaching, the author thinks that it is able to improve students' rich interest in learning national music through application of Orff teaching method which is also one of the most direct and effective ways. As a kind of famous way of music education in the world, the concept of Orff teaching method comes from ancient source. Orff thinks that the teaching is not his destination, but a method used to effectively help him to quickly realize teaching purpose. Instead of taking the theory as guidance, this teaching method starts from perception and can let learners feel national music in a more direct way. Firstly, it is required to learn how to learn; secondly, it is required to explain the reason why we need to do like this. This teaching method can let learners actively take learning in the process of happy education. In other words, the Orff teaching method 
doesn't focus on teaching students to learn the content, but focuses on actively enlightening students' inherent habit. Through game-type and extemporaneous performance, and application of natural music expression, it is able to express the emotion, be familiar with and master national music through full combination of language, action, and music, change passive state into active state, and help learners to actively learn national music.

\section{To realize the integration of ways of national music and modern music}

While China made a bid for 2008 Olympics, it used the advertising video directed by the famous director Zhang Yimou and the music Jasminum; except for showing traditional Chinese culture and great achievements made in cultural development in contemporary China in frames, the several-minute advertising video also applied many ways of modern music to implement new re-creation for traditional national music. Actually, we can realize good integration of ways of expression of traditional national music and modern music. For example, we can use electroacoustic musical instruments to perform China's traditional music, and even make a comparison between China's traditional national music and western music, modern music. In the previous traditional concepts, people are always worried that the national music may lose its original face if it is recomposed by way of expression of contemporary music and then it is not good for their accurate knowledge. In fact, as the time goes by, the difference will appear in the cultural environment where the creation personnel live as for all musical works; due to difference in understanding ability and aesthetic interest, there will be difference in music appreciation personnel at different stage of age for the effect and feelings of musical works. Therefore, it is required to take learners' deep understanding of China's national music as basis, and take aesthetic interest and accepting interest as starting point to attract students to improve their enthusiasm in national music. To realize the integration of ways of national music and modern music is a good means to cultivate contemporary students' interest in learning national music.

\section{To strive to improve music teachers' quality}

In order to undertake the heavy responsibility of music quality education and cultivate students' enthusiasm in learning national music, the teachers shall have high music quality, which means that the teachers shall have good knowledge of national music, high cultural quality, be able to perform or single rather quantity of China's national music works of different styles and forms, and be able to organize small-scale national music team to hold activities. With above basic music quality, the music teachers can truly dig out the beauty of national music and deliver the beauty to each learner so as to let them further feel the beauty of national music and motivate their strong interest in learning national music in the process of carrying out education. A successful national music teaching is not compulsorily implemented, but to thoroughly motivate students' interest. Therefore, it can be said that improving music teachers' quality is equal to owing an important stair of successful teaching.

\section{To reasonable apply extracurricular space}

Through practically enhancing the international extension of national music education, it is able to make China's music education truly become long-term and sustainable so as to exert effective consolidation function. The main practice is shown as below: the music teachers shall make good use of students' time of effective extracurricular activities, and actively organize various kinds of interest groups to cultivate high-quality learning elites; hold the appreciation meeting of national music works in some classes with high quality of national music, and arrange some extracurricular learning objectives for students. For example, it is able to organize the activity of learning a song or appreciate a famous excellent national music work on a monthly basis. Through guide learners to know high-quality musicians, it is able to create the excellent environment of China's national music education, mainly including school, family, and society, etc. In terms of school, it shall pay attention to carrying out national music education and then creating corresponding environment to maximum degree. In terms of family, the parents shall actively encourage their children to listen to music, sing the songs, and show the music as much as possible under the premise of continuously improving their personal quality. In terms of society, the broadcasting, television, and film shall carry out positive propaganda and guide, and then guide more and more people to deeply learn the music and then love China's national music. As long as the wide music educators can actively devote themselves into 
education in stronger work enthusiasm, and reasonably apply effective way of teaching, they can certainly motivate students' enthusiasm in deeply learning national music. This requires that the national music shall be able to let teachers and students get deeper feelings. In this way, we can truly feel the beauty shown by life and nature from national music, and also realize the harmony and unification of national charm and national style and form.

\section{Conclusion}

In conclusion, the purpose of China's music education is not to cultivate all students as music experts, but face toward all learners. It is required to make use of specific forms and ways of music to actively cultivate students' ability of knowing and learning national music. In this way, it is able to let learners truly know the tight combination of long national traditional culture and national music art, and let the learners' quality truly improved; furthermore, China's national music art also can be further developed and spread under the music teachers' continuous efforts.

\section{Acknowledgments}

This paper is the partial result of the youth project of Ningxia Philosophy and Social Science (Art) Planning; the project name is Research on Aesthetic Form and Value Orientation of Huaer Drama in New Period, and the project number is 14NXYCBB30.

\section{References}

[1] Sun Suqin. Discussion on Cultivating Pupils’ Interest in Learning National Music, Science \& Technology Information, 2010 (24).

[2] Zhou Feng. Let National Music Step into Students’ Soul, Learning Weekly, 2011 (5).

[3] Li Haixia. Discussion on Ways of Cultivating Students' National Emotion through National Music Teaching, School Party Construction and Ideological Education, 2012 (17).

[4] Lu Yan. How to Arouse Middle School Students’ Interest in National Music, Music Space, 2014 (15).

[5] Liu Tao, Jiang Xiansheng. Exploration on Internal Mechanism of Excellent National Music Culture on Improving Vocational College Students' Accomplishments, Higher Education Forum, 2014 (12). 